\title{
DEVELOPMENT AND OPTIMIZATION OF SOIL TREATMENT EQUIPMENT
}

\author{
Boris Tarasenko, Sergei Oskin \\ Kuban State Agrarian University, Russia \\ kgauem@yandex.ru, mechanization@kubsau.ru
}

\begin{abstract}
In the Kuban State Agrarian University an even bed for seeds was developed, reducing the lumpiness, energy consumption and removal of plant materials from the surface of the soil. The construction and technological solutions for soil-free tillage, containing paws with a lower sharpening, composite, two-tiered, folding are protected by patents. To determine their rational parameters and measure the traction resistance, a field installation was developed, and experimental samples were also made. The studies were carried out on the basis of solving optimization problems using the methods for planning experiments on a symmetric compositional plan of type Bk (stellar points are equal to \pm 1 ) according to the developed computer programs in the Mathcad system with graphs of response surfaces and optimization results.
\end{abstract}

Keywords: groundless tillage, chisels, folding paws, energy costs, optimization.

\section{Introduction}

It is known that full or partial preservation of stubble and plant residues of cultural and weed plants on the surface of the soil is intended to ensure soil protection from erosion and moisture conservation. Stubble conservation is achieved, when the working organs of soil-cultivating tools and machines are applied to the soil without changing the location of the genetic horizons and differentiating the cultivated layer according to fertility in the vertical direction, i.e. in the implementation of soil-free tillage. No-tillage processing is carried out by ploughs with removed dumps, plane cutters, paraglider ploughs, chisel ploughs (CP), cultivators and chisels. At the same time, the soil volume of the soil increases to the optimum on black soils (chernozems) and additional accumulation of moisture is provided, and when the plough is treated with a paddle, it is additionally ensured that the weeds are transferred to the upper layers [1].

However, due to the fact that these means do not fully ensure the technological quality of soil cultivation, there is a problem of their improvement. Decrease in quality can occur, for example, due to changes in the profile of the bottom (bed for seeds), and also that the rippers of the rippers do not always qualitatively divide the layer of the soil, especially if the soil is twisted or dry, so the lumps are large (150 $\mathrm{mm}$ and larger). Improvement of working bodies is also necessary to reduce the energy costs and ensure environmental safety [2]. To solve the existing problem, we presented the following research tasks:

- develop improved options for design and technological solutions;

- determine the rational design parameters of the working bodies of the developed solutions.

The implementation of the research tasks is carried out as follows.

\section{Materials and Methods}

On the basis of exploratory research, we developed and protected the following technological solutions of rippers: with chisel legs with lower and upper sharpening $[3 ; 4]$ to create an even bed for seeds and ensure the removal of plant residues to the surface of arable land; with compound chisel paws [5; 6]; with longitudinally located flat-foot paws [7]; with folding flat-paws [8] to reduce the lumpiness of the soil when processing in one pass and reduce energy costs.

For the testing of soil-cultivating working organs and for carrying out experiments to determine their rational parameters, we developed and manufactured the "Field installation" [9]. The frame "Field Machine" is pivotally connected with its bracketed plate and support. Between them is a dynamometer with a non-contact precision potentiometer mounted on it, while the arrow of the dynamometer is coaxially connected through a coupling with a potentiometer resistance regulator, and its magnetoresistive output is communicated via an analog-to-digital converter with a personal computer. Research on the definition of rational parameters was carried out using the experimental samples of working organs designed and manufactured at the Kuban State Agrarian University (Fig. 1). 

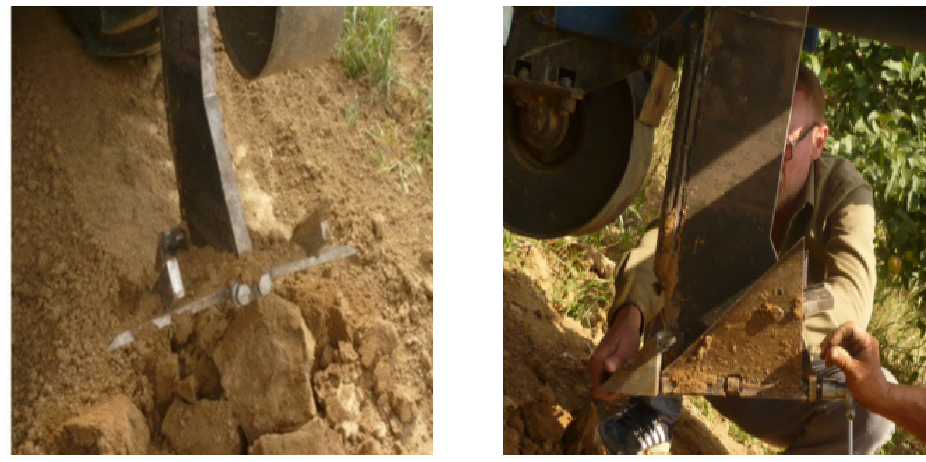

Fig. 1. Experimental sample of folding paw

The rational parameters of the working bodies of constructive technological solutions for soil cultivation were determined in the training park of the Kuban State Agrarian University and in the experimental fields in the Krasnodar territory. The investigations were carried out on the basis of the solution of optimization problems using the methods for planning experiments on a symmetric composite plan according to the developed programs [10]. The factor levels were chosen so that their optimal values fell into the center of variation. The experiments were carried out in triplicate, and the mean values were recorded in tables, in which the two-factor experiment planning matrices were presented. To exclude the influence of systematic errors caused by external factors (for example, inaccurate control, etc.), the experiments were conducted with a randomization in time, that is, in a random sequence [10]. Other factors (field humidity, total moisture capacity, bulk soil mass, specific soil mass, porosity, soil density, mean hardness) did not have significant deviations. They were tested using single-factor experiments, according to the methods of N.A. Kaczynski [10].

In this case, the designation of upper and lower factor levels by the symbols " +1 ", “-1" actually corresponds to the encoding of factors by the formula [11]:

$$
x_{i}=\frac{x_{i}+x_{i 0}}{\Delta x_{i}},
$$

where $X_{i}$ - value of the real $i$-th factor;

$X_{i 0}$ - value of the i-th factor in the middle of the interval;

$\Delta X_{i}-$ variation interval.

Thus, for the paws of the composite, with the lower sharpening, the two-tier and the folding, the following results are obtained.

The composite paw contains a stand and, made of 7-piece C-shaped bits with tubular brackets, a chisel leg. When working with such working element, the average chisel has the largest cutting angle $Q_{c}$, so it has the highest traction resistance, and for others due to blocked cutting, the traction resistance of the soil should be less by 17-20\%.

Factor analysis showed that the first variable factor $X_{1}$ is the total width of the paw $\left(b_{j}, \mathrm{~mm}\right)$, from $b_{\max }=490 \mathrm{~mm}$ to $b_{\min }=210 \mathrm{~mm}$. Variation interval $\Delta X_{1}=140 \mathrm{~mm}$. The second factor of $X_{2}$ is the angle of the paw setting $\left(\beta_{i}\right.$, deg.), varying from $\beta_{\max }=45^{\circ}$ to $\beta_{\min }=0^{\circ}$ with a variation interval $\Delta X_{2}=22.5^{\circ}$. At the same time, some of the constructive parameters of the paw are adopted as in the plow of the chisel type of the hinged type CMP (Chisel mounted plow) (the rear angle $\varepsilon=10-13^{\circ}$, the angle of sharpening $\gamma=25^{\circ}$ ), and technological factors, processing depth $a=30 \pm 1 \mathrm{~cm}$, processing speed $v=8.7 \mathrm{~km} \cdot \mathrm{h}^{-1}$ were taken close to the primary requirements.

After carrying out the experiment and, as a result of mathematical processing of the experimental data, the coefficients were determined and the following second-order regression equation was obtained in the canonical form:

$$
Y\left(x_{1}, x_{2}\right)=6124.44+2790.06 x_{1}-976.69 x_{2}-1510.00 x_{1} x_{2}+2953.55 x_{1}^{2}+1094.55 x_{2}^{2}
$$

where $Y\left(x_{1}, x_{2}\right)$ - value of the traction resistance of the working element, $\mathrm{N}$;

$x$ - coded value; while the coefficients are checked by the Student's test, and the equation by the Fisher criterion. 
Differentiating the equation, for each of the variables and equating the derivatives to zero, we obtain a system of linear equations. Having solved the obtained system, we find the coordinates of the response center: in the coded values $x_{1}=-0.435$ and $x_{2}=0.146$, which corresponds in real values $X_{1}=289.1 \mathrm{~mm}, X_{2}=25.78^{\circ}$.

To analyze the factors after the canonical transformation, we obtain the equation:

$$
Y-Y_{s}=3221.54 X_{1}^{2}+826.55 X_{2}^{2}
$$

where $X_{1}, X_{2}$ - canonical variables;

$Y_{s}-$ value of the output variable at the center of the response surface, $Y_{s}=5446.29, \mathrm{~N}$.

The angle of rotation of the axes was $-\alpha=-19.54^{\circ}$.

We substitute the obtained values into the obtained initial equation (3) and find the value of the parameter at the center of the response surface. The value of the optimal value of tractive resistance of the working organ $Y_{s}=4157.06 \mathrm{~N}$.

According to equation (3), the surface of the response of the tensile resistance of the working member from the width of the foot $\mathrm{b}$ and the angle of crumbling $\beta$, the surface of the response in the isolines and the graphs have the following forms (Fig. 2, 3).

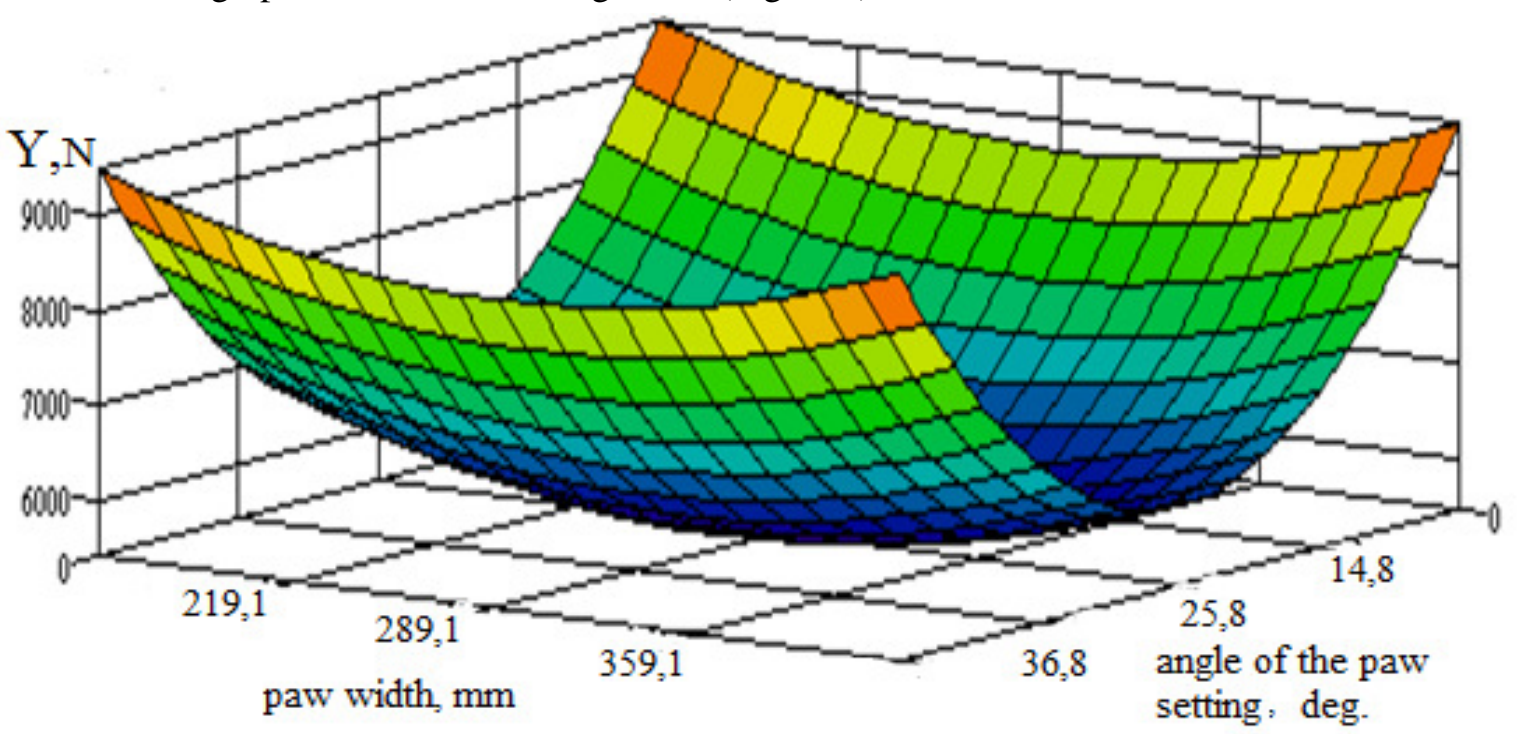

a)

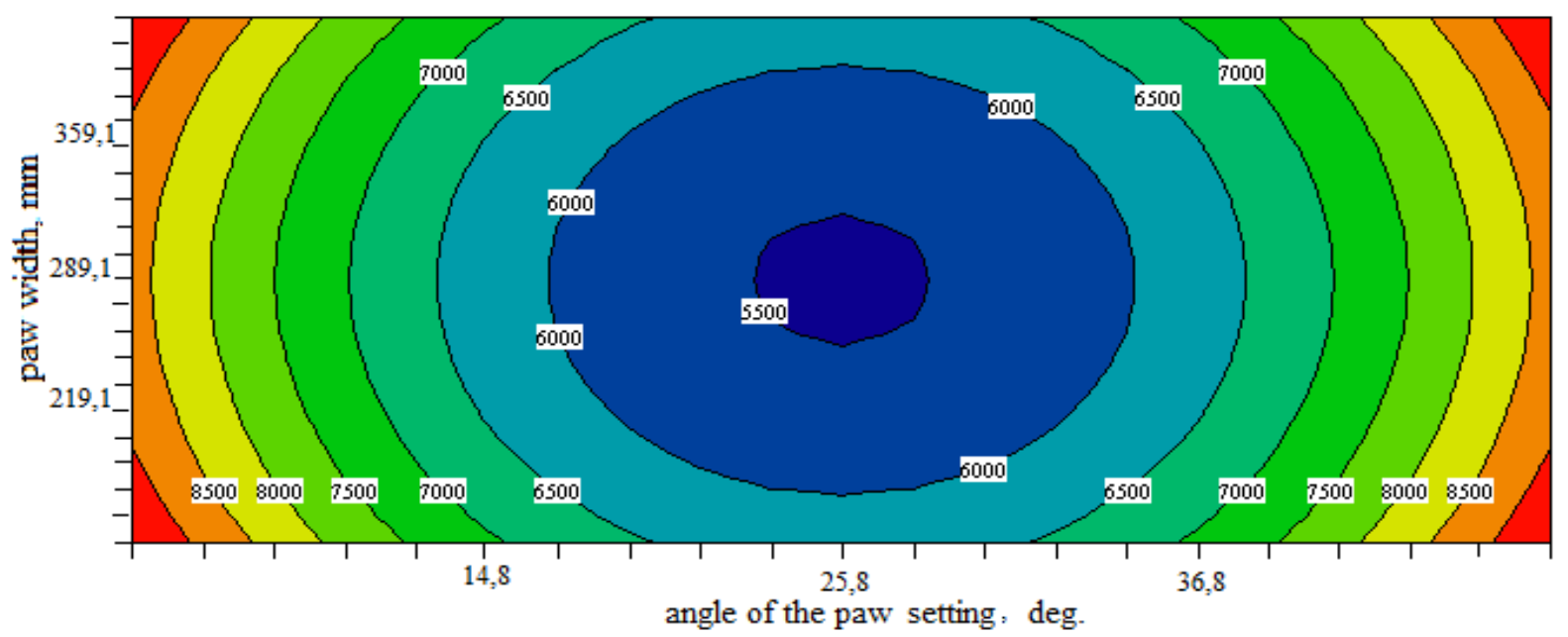

b)

Fig. 2. Surfaces of dependence of tractive resistance on angle of crumbling and width of paw: $a$ - response surface; $b$ - two-dimensional section 

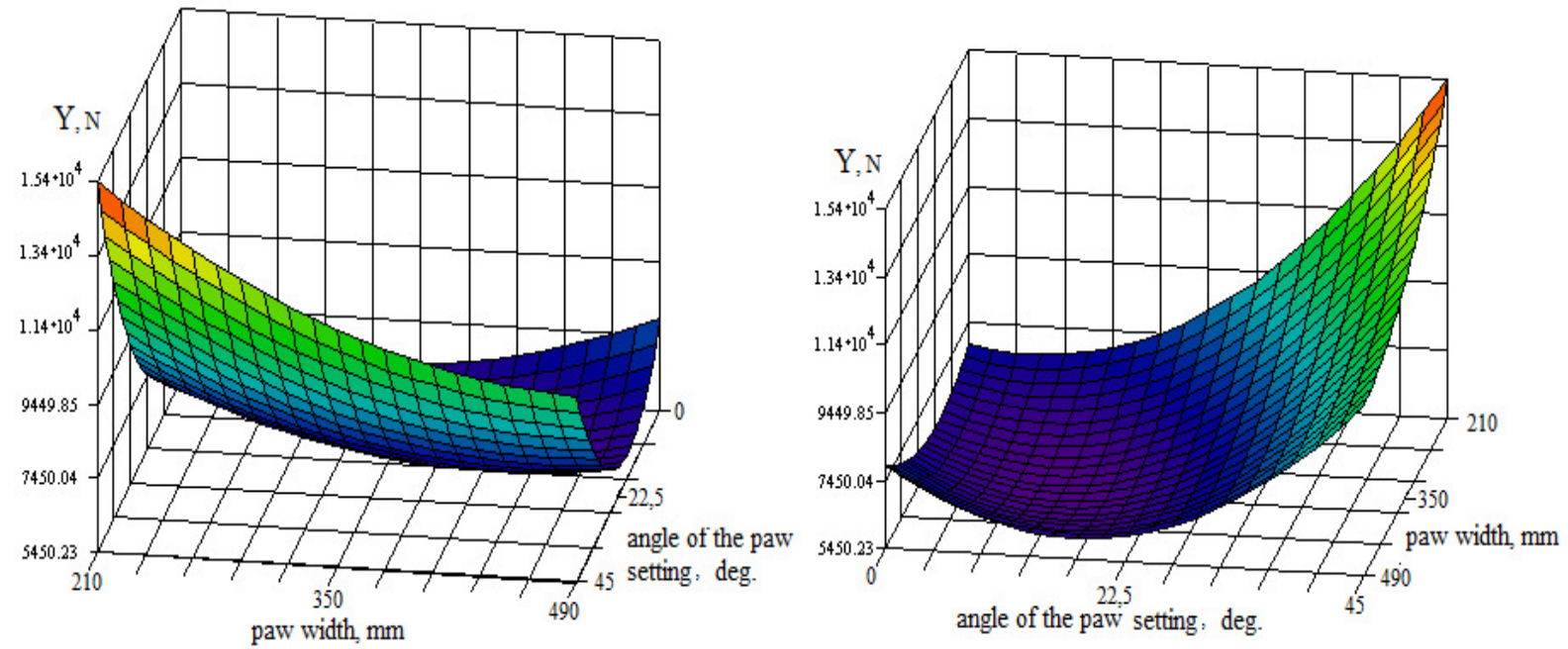

Fig. 3. Surfaces of dependence of tractive resistance on angle of crumbling and width of paw: graphics

Referring to Fig. 4 shows the dependence of the drag of the working member on $b_{i}$ and $\beta_{j}$ for fixing the parameters $X_{1}$ and $X_{2}$.

a)

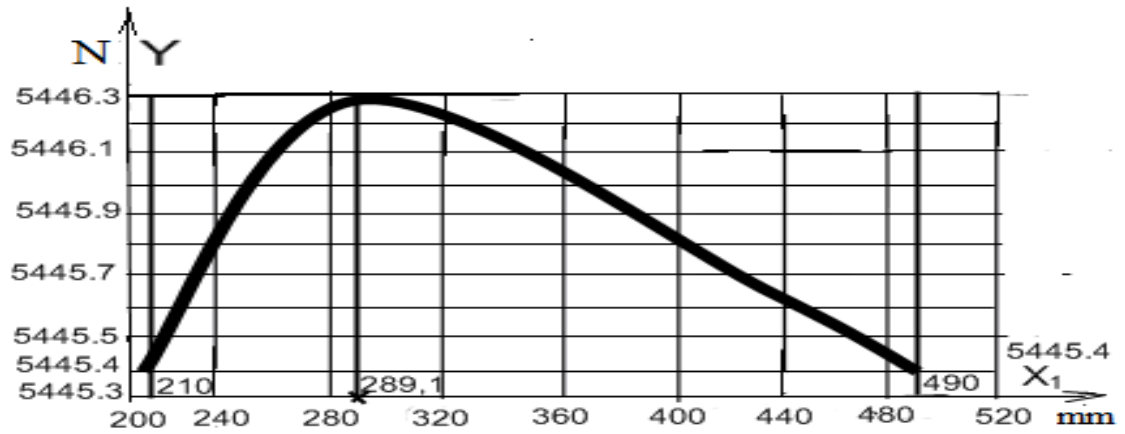

b)

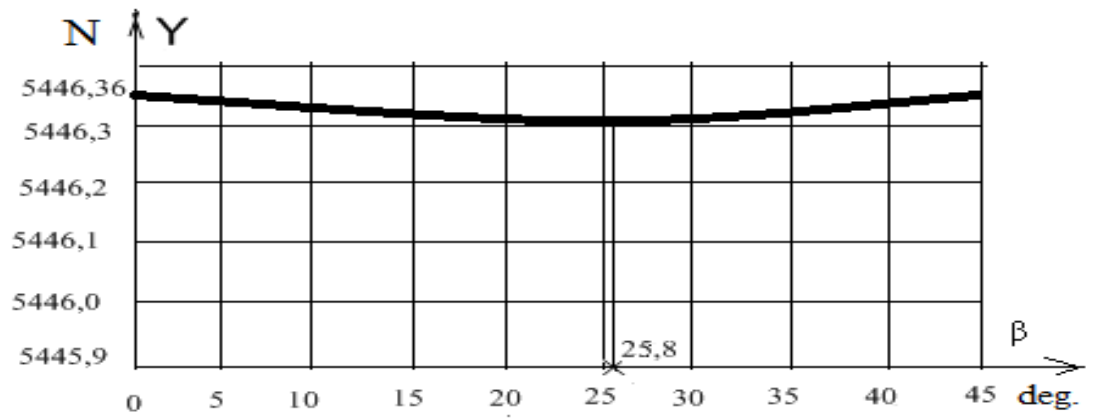

Fig. 4. Traction resistance working organ from $\boldsymbol{b}_{\boldsymbol{i}}$ and $\boldsymbol{\beta}_{j}$ :

$\mathrm{a}$ - for a fixed parameter $X_{1} ; \mathrm{b}$ - for a fixed parameter $X_{2}$

For paws with a lower sharpening in the analysis of factors it is established that the first variable factor $X_{1}$ is the width of the paw $\left(b_{j}, \mathrm{~mm}\right)$ with a variation interval $\Delta X_{1}=215 \mathrm{~mm}$, varying from $b_{\max }=500 \mathrm{~mm}$ to $b_{\min }=70 \mathrm{~mm}$. The second factor $X 2$ is the angle of crumbling $\left(\beta_{i}{ }^{\circ}\right)$, from $\beta_{\max }=40^{\circ}$ to $\beta_{\min }=30^{\circ}$ with a variation interval $\Delta X_{2}=5^{\circ}$. A part of the constructive parameters of the paw is adopted as for the plow of the chisel hinged type CMP (the rear angle $\varepsilon=10-13^{\circ}$, the angle of sharpening $\gamma=25^{\circ}$ ), and the processing depth $a=15 \pm 1 \mathrm{~cm}$, processing speed $v$ up to $9 \mathrm{~km} \cdot \mathrm{h}^{-1}$ (in our case $8.7 \mathrm{~km} \cdot \mathrm{h}^{-1}$ ) were adopted close to the primary requirements.

The equation of regression in the canonical form, for determining the traction resistance $Y(x), \mathrm{N}$ of the composite paw, is:

$$
Y\left(x_{1}, x_{2}\right)=4024.26+790.02 x_{1}+443.34 x_{2}-1618.46 x_{1}^{2}+1296.95 x_{2}^{2} \text {. }
$$


Solving the system of linear equations, we find the coordinates of the response center: in the coded values $x_{1}=0.24$ and $x_{2}=0.17$, which corresponds to the real values $X_{1}=336.6 \mathrm{~mm}, X_{2}=35.85^{\circ}$.

Substituting them in the initial equation, we find the value of the parameter at the center of the response surface. The value of the optimum value of the traction resistance of the working member is $Y_{s}=4157.5 \mathrm{~N}$.

For the two-level paw in the analysis of factors, we established that the first variable factor $X 1$ is the depth of processing $\left(a_{i}, \mathrm{~m}\right)$, from $a_{\max }=0,5 \mathrm{~m}$ to $a_{\min }=0,3 \mathrm{~m}$. Variation interval $\Delta X_{1}=0.1 \mathrm{~m}$. The second variable factor $X_{2}$ is the inter-tier distance $\left(h_{i}, \mathrm{~m}\right) . X_{2}$ varies from $h_{\max }=0,2 \mathrm{~m}$ to $h_{\min }=0.1 \mathrm{~m}$ with an interval $\Delta X_{2}=0.05 \mathrm{~m}$. The design parameters of the paw are the same as those of the CMP, and the processing speed was adopted close to the primary requirements and was $8.7 \mathrm{~km} \cdot \mathrm{h}^{-1}$.

The regression equation in the canonical form is:

$$
Y\left(x_{1}, x_{2}\right)=3999.2+166.7 x_{1}-533.4 x_{2}-1346.2 x_{1}^{2}-1150.5 x_{2}^{2} .
$$

The obtained coordinates of the response center in the coded values are $x_{1}=0.062$ and $x_{2}=-0.23$, which corresponds in real values $X_{1}=0.41 \mathrm{~m}, X_{2}=0.14 \mathrm{~m}$. The value of the optimum value of the tensile resistance of the working member $Y_{s}=4066.2 \mathrm{~N}$.

For the folding paw, in analyzing the factors, it is established that the value for the first factor $X 1$ is the bit angle of the bit with a variation interval of ten degrees, from $\beta_{\min }=35^{\circ}$, to $\beta_{\max }=45^{\circ}$, $\Delta X_{1}=5^{\circ}$.

The maximum value for the second factor $X_{2}$ is the bit width, the interval of sizes is $0.07-0.11 \mathrm{~m}$, which corresponds to the variation interval $\Delta X_{2}=0.02 \mathrm{~m}$; the maximum and minimum value for the third factor $X_{3}$ was the length of the working surface of the bit from $0.18 \mathrm{~m}$ to $0.08 \mathrm{~m}, \Delta X_{3}=0.05 \mathrm{~m}$.

The height of the bit was not fixed, since these quantities are dependent on the working length of the bit $\ell$ and as a factor of variation it has not been considered; for the fourth factor $X 4$ of the displacement speed of the working member, a range of variation from 4 to $8 \mathrm{~km} \cdot \mathrm{h}^{-1}, \Delta X_{4}=2 \mathrm{~km} \cdot \mathrm{h}^{-1}$, is adopted.

$$
\begin{gathered}
Y\left(x_{1}, x_{2}\right)=2085+6.67 x_{1}+0.46 x_{2}+1.45 x_{3}+11.15 x_{4}+0.72 x_{1} x_{2}+0.166 x_{1} x_{3}+8.55 x_{1} x_{4}- \\
-2.3 x_{3} x_{2}+1.31 x_{4} x_{2}+0.79 x_{3} x_{4}-2.35 x_{1}^{2}-0.185 x_{2}^{2}-0.129 x_{3}^{2}+10.75 x_{4}^{2} .
\end{gathered}
$$

At $Y_{s}=2085 \mathrm{~N}(2.085 \mathrm{kN})$, the optimal bit width was $b=98,86 \mathrm{~mm}$; the optimal length of the working part of the bit is $\ell=122.4 \mathrm{~mm}$; the optimum bit angle of the bit is $\beta=41.45^{\circ}$; speed of moving the gun with the lowest energy intensity of the process $v=(4.69) 4-5 \mathrm{~km} \cdot \mathrm{h}^{-1}$.

\section{Conclusions}

To create an even bed for seeds, reduce clodiness, energy consumption and removal of plant materials from the surface of the soil, tools have been developed and protected by patents with improved working organs for soil-free tillage, containing paws with a lower sharpening, composite, two-tiered, folding.

Experimental mathematical models in the form of regression equations of the second order are presented, which allows one to obtain new coordinates of the response center points, when solving linear equation systems, and to minimize or maximize the energy parameters.

Rational parameters based on the solution of optimization problems are as follows: the composite paw $Y_{s}=5446.3 \mathrm{~N}, b=289.1 \mathrm{~mm}, \beta=25.8$; the paws with a lower sharpening $-Y_{s}=4157.5 \mathrm{~N}$, $b=336.6 \mathrm{~mm}, \beta=35.85^{\circ}$; the two-level paw $Y_{s}=4066.2 \mathrm{~N}, a=0.41 \mathrm{~m}, h=0.14 \mathrm{~m}$; of the folding paw $Y_{s}=2085 \mathrm{~N}$, bit width $b=98.86 \mathrm{~mm}, \ell=122.4 \mathrm{~mm}, \beta=41.45^{\circ}$.

\section{References}

[1] Зеленский Г.Л., Чеботарев М.И., Трубилин Е.И. Рис: новые сорта и энергосберегающие технологии его культивации в Краснодарском крае (научно-методологическая разработка). (Rice: New varieties and energy-saving technologies of its cultivation in the Krasnodar Territory (scientific and methodological development)). Krasnodar: KubGAU. 1997. 96 p. (In Russian) 
[2] Тарасенко Б.Ф., Оськин С.В. Интегрированный подход к технологиям производства зерновых культур. (Integrated approach to the technology of cereal crops production. Polytematic network electronic scientific journal of the Kuban State Agrarian University 2013. №87 (03). pp. 123-137. (In Russian)

[3] Патент РФ №2316921, МПК А01В49/02. Рыхлитель чизельный / Б.Ф. Тарасенко, А.Н. Медовник, В.Д. Карпенко и др.; патентообладатель ФГОУ ВПО КубГАУ; опубл. 20.02.2008, БИ №5. (The patent of the Russian Federation № 2316921, МПК А01В49 / 02. Ripper chisel / B.F. Tarasenko, A.N. Medovnik, V.D. Karpenko and others; publ. 02/20/2008, Bulletin of Inventions № 5.)

[4] Патент РФ №2297127, МПК А01B49/06, А01С7/00. Посевной агрегат / Б.Ф. Тарасенко, В.С. Курасов, Е.И. Трубилин и др.; патентообладатель ФГОУ ВПО КубГАУ; опубл. 20.04.2007, БИ №11. (The patent of the Russian Federation №2297127, МПК A01B49 / 06, A01C7 / 00. Sowing unit / B.F. Tarasenko, V.S. Kurasov, E.I. Trubilin and others; publ. 04/20/2007, Bulletin of Inventions № 11.)

[5] Патент РФ №2214076, МПК А01В13/08. Устройство для безотвальной вспашки / Б.Ф. Тарасенко, М.И. Чеботарёв, И.А. Ключников и др.; патентообладатель ФГОУ ВПО КубГАУ; опубл. 20.10.2003, БИ №29. (The patent of the Russian Federation №2214076, МПК A01B13 / 08. The device for beetleless plowing / B.F. Tarasenko, M.I. Chebotarev, I.A. Klyuchnikov and others; publ. 10/20/2003, Bulletin of Inventions № 29.)

[6] Патент РФ №2267893, МПК А01В79/02, А01B49/06. Способ безотвальной обработки почвы и устройство для его осуществления / Б.Ф. Тарасенко, В.М. Прощак, Ю.М. Щуров и др.; патентообладатель ФГОУ ВПО КубГАУ; опубл. 20.01.2006, БИ №2. (The patent of the Russian Federation № 2267893, МПК А01B79 / 02, A01B49 / 06. Method of soil-free tillage and device for its implementation / B.F. Tarasenko, V.M. Proshchak, Y.M. Shchurov and others; publ. 01/20/2006, Bulletin of Inventions № 2.)

[7] Патент РФ №2189127, МПК А01B49/02, А01B3/36. Плуг навесной / В.П. Заярский, О.Б. Селивановский, Б.Ф. Тарасенко и др.; патентообладатель ООО Краснодаррисмаш; опубл.20.09.2002, БИ №26. (The patent of the Russian Federation №2189127, МПК А01В49 / 02, A01B3 / 36. Plow mounted / V.P. Zayarsky, O.B. Selivanovsky, B.F. Tarasenko and others; publ. 20/09/ 2002, Bulletin of Inventions № 26.)

[8] Патент РФ №2298302, МПК А01В 35/28, А01В35/26. Устройство для обработки почвы / А.Н. Медовник, Б.Ф. Тарасенко, С.А. Твердохлебов; патентообладатель ФГОУ ВПО КубГАУ; опубл. 10.05.2007, БИ №13. (The patent of the Russian Federation № 2298302, МПК A01B 35/28, A01B35 / 26. A device for tillage / A.N. Medovnik, B.F. Tarasenko, S.A. Tverdokhlebov; publ. 05/10/2007, Bulletin of Inventions № 13.)

[9] Патент РФ №2436270, А01B63/112, 5/13. Полевая установка для испытаний почвообрабатывающих рабочих органов. / Б.Ф. Тарасенко, Н.И. Богатырёв, А.Н. Медовник и др.; патентообладатель ФГОУ ВПО КубГАУ; опубл. 20.12.2011, БИ №35. (Patent of the Russian Federation No. 2436270, A01B63 / 112, 5/13. Field installation for testing of soilworking tools. / B.F. Tarasenko, S.A. Tverdokhlebov, N.I. Bogatyrev and others; publ. 12/20/2011, Bulletin of Inventions № 35.)

[10] Оськин С.В., Тарасенко Б.Ф. Эффективные комплексы почвообрабатывающих агрегатов. (Effective complexes of soil-processing units). Krasnodar: KubGAU. 2016. 380 p. (In Russian)

[11]Бондарь А.Г., Статюха Г.А. Планирование эксперимента в химической технологии (Planning an experiment in chemical technology). Publishing Association "Visha School", 1976, 184 p. (In Russian) 